\title{
International Legal Challenges on Biotechnological Products
}

\author{
Saeed Daryaee Bajhdadabadi ${ }^{1}$, Mohammah Hossain Ramazani Ghavamabadi ${ }^{2}$, Seyed Ghasem Zamani $^{3}$ \& \\ Mehrzad Kiani ${ }^{4}$ \\ ${ }^{1}$ Department of Public and International Law, Science and Research Branch, Islamic Azad University, Tehran, \\ Iran \\ ${ }^{2}$ Department of International Law, Shahid Beheshti University, Tehran, Iran \\ ${ }^{3}$ Faculty of Law and Political Sciences, AllamehTabatabai University, Iran, Tehran, Iran \\ ${ }^{4}$ Faculty of Traditional Medicine, Medical Ethics Department, Shahid Beheshti University of Medical Sciences, \\ Tehran, Iran \\ Correspondence: Mohammah Hossain Ramazani Ghavamabadi, Department of International Law, Shahid \\ Beheshti University, Tehran, Iran. E-mail: h_ramezani@sbu.ac.ir
}

Received: May 28, 2016 Accepted: June 28, 2016 Online Published: August 30, 2016

doi:10.5539/jpl.v9n7p247 URL: http://dx.doi.org/10.5539/jpl.v9n7p247

\begin{abstract}
Selection and separation of inheritance has the desired characteristics of plants, animals and organisms have specific morphological characteristics and called them in terms of biotechnology. Including applications help farmers to reduce the amount of fertilizers, chemical pesticides, water and fuel consumption for the production of food As well as biotechnological products can be used for purification and cleansing the environment and food production at lower costs and reduce the use of harmful chemicals to human health and the environment. However, criticism has been leveled on biotechnology, for example, genetically modified organisms, unlike chemicals, have a risk of spread and replication capabilities and unknown toxins may be produced by biotechnological products or reduce biodiversity, genetic contamination and poisoning and destroy beneficial insects harmless. This article, in addition to addressing various aspects of biotechnology, seeking to assess the strengths and limitations of current international law and structures designed to address these concerns communities. Biotechnology problems at the international level and treaties related to each of them are as follows: A) Concerns about patent genetically modified crops: National rules developed countries, genetically modified crops have to support intellectual property. If to be biotech crops intellectual property rights, the bulk of the food of world award to several capitalist companies .B) Concerns about Transparency Regarding Exports of Genetically Modified Products: Notification of genetically modified content could be achieved through a labeling system C) Liability for damage caused by genetically modified imported products: The international community have tried to establish international rules on liability and compensation for damage caused by genetically modified crops that in the Biosafety Protocol, the provisions limiting the harmful effects caused by genetically modified organisms. D) Liability of Trans boundary damage caused by genetically modified crops: Genetically modified crops could have a negative impact on the environment of neighboring states, even if completely in a state of production and consumption.After careful consideration of the above it can be concluded that there is not a single treaty regime and specific concerns to address the biotechnology. But we are faced to fragmented and conflicting network of treaties relating to intellectual property, trade and the environment, as well as a series of general principles of law and legal norms ambiguous.
\end{abstract}

Keywords: biotechnological products, international law, international challenges, patents, damages

\section{Definition and Applications of Biotechnology}

Biotechnology encompasses a variety of techniques Such as separating the natural inheritance and selection of an organism that is desired properties, The hybrid cells from fusing different parental resources, The use of radioactive substances or chemicals to create mutant hereditary characteristics, Genetic engineering of plants, animals, living creatures small to contain specific morphological.In total, biotechnology called different techniques using living organisms or parts of organisms to make or modify products, plant breeding and rearing 
animals or microorganisms for special applications. ${ }^{1}$

Each cell of a living organism is typically a core which includes components are very thin which is known as chromosomes. Each chromosome contains strings of nucleotides (each of a nitrogen base, a sugar and a phosphate molecule) the nucleotides themselves are structured in two complementary screw series regularly and form DNA. A sequence of nucleotides on a chromosome contains within it a particular piece of information about the organism's parent: that sequence is known as a gene. ${ }^{2}$ Using such techniques, scientists are capable of joining DNA fragments from different sources to create novel DNA (known as recombinant DNA or rDNA) so as to take a valued quality of one organism and join it with the valued quality of a second organism.

The scientists also expect that treat some patients through gene therapy and transfer and inject a corrective gene to the patient who has the defective gene or gene is lacking. ${ }^{3}$ Or even through the interaction between different genes, treat diseases such as cancer or Alzheimer and even gene therapy treatment make a higher human life and people smarter. ${ }^{4}$ Insects harmful to the agricultural economy have grown with disinfection properties in order to when released to reduce their population numbers. ${ }^{5}$

Genetically modified microorganisms might be developed that, when released into the environment, may help control soil acidity/alkalinity or salinity, thereby increasing geographic range of crops Products have been genetically modified In order to better survive in drought or frost ${ }^{6}$ Or to stay fresh longer ${ }^{7}$ Or to resist various aphtous ulcers and diseases ${ }^{8}$ And for resistance to herbicides Which allows farmers to spray herbicides on fields without damaging the product. ${ }^{9}$ A similar biotechnological tools can be used to apply for animals to improve the quality and quantity of milk, eggs, meat or wool, or even produce healthier animals. ${ }^{10}$ In addition, the global application of biotechnology in agriculture can help farmers around the world to reduce the use of fertilizers, chemical pesticides and water consumption and fuel for food production and produce foods that cost less And less harmful to human health and the environment from chemicals that are used. ${ }^{11}$

Not only can supply increase But foods can be engineered and designed with higher nutritional value and the amount of vitamins and healthier fats and in tropical countries remain fresh for longer. ${ }^{12}$ Although there are environmental concerns about the harmful effects caused by the manipulation of nature by Biotechnology But it should be noted that the positive uses of biotechnology can be variety Such as genetic engineering products to need for less production factors like land, water and pesticides. A potential benefit of using biotechnology to purify and cleanse the environment. With the advent of genetic engineering, a bunch of national and international concerns were raised.

Many consumer and environmental groups believe that genetically modified crops are inherently risky and should not be extended before extensive testing and long-term .In particular, critics point out that unlike chemicals and hazardous waste, genetically modified organisms, have also the risk to the wide dissemination and replication. ${ }^{13}$

Concerns have been raised on various potential aspects of new biotechnology and Including unknown toxins, antibiotic resistance, religious violations, counterfeit and fake freshness, genetic pollution And other harmful effects arising from the entry of toxic organisms in the ecosystem.Critics of Engineering and Biotechnology,

\footnotetext{
1 - Cooper, Iver P., Biotechnology and the Law, Thomson, West Group 2003, Volumes 3.

2 - BIOTECHNOLOGY: SCIENCE, ENGINEERING, AND ETHICAL CHALLENGES FOR THE TWENTY-FIRST CENTURY (Frederick

B. Rudolph \& Larry V. McIntire, eds. 1996).

3 - Rick Weiss \& Justin Gillis, DNA-Mapping Heralded, WASH. POST, June 27, 2000, at A1.

4 - Ya-Ping Tang et al., Genetic Enhancement of Learning and Memory in Mice,401 NATURE 63 (Sept. 2, 1999).

5 - David A. O’Brochta \& Peter W. Atkinson, Building the Better Bug, SCI. AM., Dec. 1998, at 90.

6 - SHELDON KRIMSKY \&ROGER P.WRUBEL,AGRICULTURAL BIOTECHNOLOGY AND THE ENVIRONMENT 154-65 (1996).

7 - Calgene, Inc., Availability of Letter Concluding Consultation, 59 Fed.Reg. 26,647 (Dep't Health \& Human Services 1994).

8 - Michael Pollan, Playing God in the Garden, N.Y. TIMES, Oct. 25, 1998,6Magazine at 44.

9 - Monsanto Press Release on Environmental Benefits Of Crops Developed Through

Biotechnology (July, 1997), <http://www.monsanto.com/monsanto/mediacenter./background/97jul_Env Benefits .html>.

${ }^{10}$ - SHELDON KRIMSKY \&ROGER P.WRUBEL,AGRICULTURAL BIOTECHNOLOGY AND THE ENVIRONMENT 154-65 (1996),

11 - Robert B. Horsch, Biotechnology and Sustainable Development, in BIOTECHNOLOGY AND BIOSAFETY 25 (Ismail Serageldin \& Wanda Collins eds., 1999).

12 - Xudong Ye et al., Engineering the Provitamin A (ß-Carotene) Biosynthetic Pathway into (Carotenoid-Free) Rice Endosperm, 287 SCI. 303 (2000).

13 - M. CHIARA MANTEGAZZINI, THE ENVIRONMENTAL RISKS FROM BIOTECHNOLOGY (1986)
} 
argue that modified crops that are designed for human or animal consumption .They have uncontrolled adequately By competent authorities such as local and national government through regulations America.

In fact, such products are not tested in terms of long-term effects on human health,Nevertheless modified crops to some extent by existing legislation on food, medicine, agriculture and the environment Are set by organizations such as the Food and Drug Administration (FDA) or the United States Department of Agriculture (USDA) and the Environmental Protection Agency (EPA). ${ }^{14}$ Although does not exist scientific evidence for any damage arising from the use of genetically modified. ${ }^{15}$

Critics say that more studies should be carried out by scientists about the risks of genetically modified crops for human healthIn addition, critics are concerned about the environmental impact of genetically modified crops. ${ }^{16}$ Critics fear that plants with another plant gene disturb the ecosystem balance because they are not predictable and in the long term can be very harmful to the environment.

Genetically modified products to poison the insects, May inevitably lead to the poisoning of insects are harmless or beneficial insects When feed from pests And so in fact increase the number of pests And reduces the biodiversity of insects

\section{Biotechnology Problems}

If biotechnology successfully produce revolutionary and vigorous abilities, the international community is forced to Provide a degree of international cooperation is desirable and required (for ethical, economic and political reasons) to regulate and control these abilities and funding for this feature To make available to those who need it. $^{17}$

Major contemporary concerns can be divided in several categories:

1. Concerns about granting a patent to genetically modified crops. 2. The need to inform the importer of these products and determining the amount of details that need to be addressed in this Declaration. 3. The conditions under which states may refuse of allowing modified crops import, in terms of coordination with international trade rules. 4. The responsibility for the harmful effects of these products on human health and the environment of the importing country. 5. Liability for the harmful effects of genetically modified crops, Although it is produced and consumed in the country of origin, however, have detrimental effects on health and environment of neighboring states. 6 . The potential loss for the current generation and the future of the world's biodiversity to release modified crops on the environment

\section{The First Challenge: Patents}

There are important concerns related to modified crops in the field of patents especially in the field of agriculture and pharmaceuticals. These concerns fall into two categories:

A) The developed countries argue that intellectual property rights must be supported on modified crops In order to strengthen and promote research and the development of these products, While developing countries argue that the protection of intellectual property rights, access to these products will be expensive for developing countries Or even this will prevent access That In both cases, Would be inappropriate For their life

B) developed states tend to have unlimited access to a rich genetic diversity found in developing countries, as an essential resource for genetic engineering, while developing countries argue that the benefits of genetic resources found in their countries should be divided fairly. ${ }^{18}$

In relation to the first field Concerned about grant and protection of intellectual property rights on genetic modified crops Intellectual property rights of America

Did not claim ownership or use of natural phenomena such as genetic resources Therefore access to these resources are unlimited.However, once novel products or processes are developed from genetic resources, then U.S. law may provide intellectual property protection. Thus, a naturally occurring substance, whether living or

\footnotetext{
14 - Toxic Substances Control Act (TSCA), 15 U.S.C. 2601-2629 (1994)

15 - COMMITTEE ON GENETICALLY MODIFIED PEST-PROTECTED PLANTS, NATIONAL

RESEARCH COUNCIL, GENETICALLY MODIFIED PEST-PROTECTED PLANTS:SCIENCE AND REGULATION (2000), $<$ http://books.nap.edu/catalog/9795.html $>$.

16 - James Kling, Could Transgenic Supercrops One Day Breed Superweeds? 274 SCI. 180 (1996);

17 - Michael J. Malinowski, Globalization of Biotechnology and the Public Health Challenges Accompanying It, 60 ALB. L. REV. 119 (1996).

18 - CLIVE JAMES \&ANATOLE F. KRATTIGER, GLOBAL REVIEW OF THE FIELD TESTING AND COMMERCIALIZATION OFTRANSGENIC PLANTS, 1986 TO 1995
} 
inanimate, in principle can be patented if it is isolated from its surroundings, identified and made available for the first time, and has a useful purpose. Office of trademarks and patent in the United States ${ }^{19}$ At first doubted the ability to grant patent to small organisms But the Supreme Court decided that the issuance of a patent for such products is possible under the law of America As long as a person can be said to have invented Or discovered A construction or a combination of an article that have Names, and distinctive features. ${ }^{20}$

The study of agricultural seeds will help to clarify the international results and effects of recognition of such patents of genetically modified crops, Until recently, farmers bought seeds Or they divided together at the local level In recent decades, farmers began purchasing seeds nationally and transnationally from large companies but, even then, the fact that plants grown from the seeds produced a second generation of seeds largely left the various strains of seeds available to all farmers for use and experimentation. However, the control of agricultural seeds may shift from farmers worldwide to just a few multinational biotechnology companies. ${ }^{21}$

When the seeds of genetically modified plants are exported by US companies, foreign importer must conclude a license agreement on the use of the product with exporter. Is hereby authorized importer of the product to develop a single generation?

When that product was produced it is owned by the permit holder. Although its genes remain in the ownership of US Company and are under the protection of patent law of America If the importer attempt to produce the second generation of the product, License agreements and patent law of America has been violated. About Intellectual property laws of Other developed countries It must be said That there is consensus on this subject That protection of intellectual property can not be generalized to genetic resources That are merely found in nature And the involvement of human initiative Had not role In the creation of them. ${ }^{22}$

In addition, developed countries have followed America's view about granting patent licenses for small organisms and genetically modified plants and animals.

Several states have adopted a treaty designed to coordinate in order to achieve a patent on living organisms. ${ }^{23}$

Despite the fact that developing countries are aware of the benefits of genetically modified crops - For example, the science of biotechnology has led to the production of disease-free and vaccinated bananas in Central AfricaBut still many of them oppose the recognition of intellectual property rights for these products.

This opposition Is In terms of Moral aspects Which believes life forms and biodiversity of human beings are not reducible to property rights Because it requires the possession of a group And depriving others of it. In addition, developing countries are concerned that granting intellectual property rights to genetically engineered crops only to a limited number of multinational biotechnology companies in developed countries Allows them that set high prices for licensing the use of products that are needed by developing countries.

In this respect, Convention on Biological Diversity tries to consider the concerns about ensuring access to materials and genetic resources And at the same time promote equitable distribution of materials and products derived from genetically modified. ${ }^{24}$

The conservation of biological diversity, the sustainable use of its components and the fair and equitable sharing of the benefits arising out of the utilization of genetic resources, including by appropriate access to genetic resources and by appropriate transfer of relevant technologies, taking into account all rights over those resources and to technologies, and by appropriate funding.

The Convention is an important step towards the development of the international regime of Biotechnology But the criticism was that rules and regulations are very general and leave many things unsaid. Unfortunately, formal negotiation of the Convention began in 1991 and was completed hurriedly in time for the 1992 Rio Summit. The hurried pace left insufficient time for the disparate views of states to converge, resulting in a text that is often times unclear, ambiguous or even contradictory, Convention and its negotiations

Was not able to pay attention to the interests of the state and private actors comprehensively.

\footnotetext{
19 - Office of trademarks and patent in the United States

20 - John M. Czarnetzky, Altering Nature's Blueprints for Profit: Patenting Multicellular Animals, 74 VA. L. REV.1327 (1988).

21 - Monsanto Press Release on Environmental Benefits Of Crops Developed Through Biotechnology (July, 1997), $<$ http://www.monsanto.com/monsanto /background/97julEnvBenefits .html >.

22 - PHILIP W.GRUBB, PATENTS FOR CHEMICALS, PHARMACEUTICALS ANDBIO TECHNO LOGY 213 -14 (1999).

23 - Budapest Treaty on the International Recognition of the Deposit of Microorgans for the Purposes of Patent Procedure, Apr. 28, 1977, 32 U.S.T. 1241, 17 I.L.M. 285.

${ }^{24}$ - Convention on Biological Diversity, June 5, 1992, 31 I.L.M. 818, 823.
} 
As a result, although its provisions could affect the behaviors and actions of international But it is unsuccessful in regulating their behavior. In a more detailed examination of this Convention. It should be noted that the Convention specifically dedicated an article to access to genetic resources. ${ }^{25}$ And states that: With considering the sovereign right of states over their natural resources, they have authority to determine access to genetic resources by national legislation. Each Contracting Party "shall endeavour to create conditions to facilitate access to genetic resources for environmentally sound uses by other Contracting Parties" And does not impose any restrictions that are contrary to the objectives of this Convention. The Convention, in Article 16, deals about the access and transfer of technology And states: Each of the member countries confirm that biotechnology is a kind of technology And that access to and transfer of technology among member countries, is an essential element for the purposes of this Convention, According to the provisions of this Article states shall provide the necessary facilities for other Member States to access and transfer of technologies relating to the conservation and sustainable use of biodiversity and genetic resources That does not cause considerable damage to the environment. ${ }^{26}$

In addition, Article 19 also discusses about management of of Biotechnology and distribution of its benefits And states that member states must do each of the executive and legislative or policy measures as appropriate to ensure the effective participation of other countries (Especially developing countries) in biotechnological research activities. ${ }^{27}$

\section{The Second Challenge: Export}

The second issue of biotechnology at the international level are concerns about the appropriate level of transparency When genetically engineered products exported from one country to another.A state Can provides Rules and national law for setting up, development and application of products that are imported from abroad to assess the risks of modified crops for human health or the environment (or for other reasons) State needs to an efficient system to identify such products at the point of entry into the country ${ }^{28}$ Or to receive information from the importer or the exporter Inform or declaration the modified crops can be achieved through the labeling system For example, in 1997 the Europe Union passed a law Which requires the labeling of certain products consisting of or containing genetically modified crops. ${ }^{29}$

In 1999, a record about the need for labeling of foods made from genetically modified material was delivered to Congress of America. ${ }^{30}$ Of course there are problems in the way of labeling schemes.For example, governments should establish standards for determining genetic content that if these measures are not in harmony together the different standards, can interrupt the flow of commerce.In relation to the promotion of transparency, the parties to the Convention on Biological Diversity conducts negotiations over 5 years and finally in 2000 Biosafety Protocol was adopted in Nairobi. ${ }^{31}$

This protocol is an international framework for addressing environmental risks and effects of some genetically modified crops established The Convention aims to help to ensure an adequate level of protection against harmful effects on the conservation and sustainable use of biodiversity, and also consider the risks of these products for human health. ${ }^{32}$

Specifically, the Protocol allows trade in genetically modified products to proceed essentially unhindered, subject to two conditions. First, living modified organisms (LMOs) shipped in bulk as commodities (e.g., soy or corn) and that are intended to be used as food, feed, or for processing must be accompanied by documentation stating that such shipments "may contain" LMOs and are not intended for intentional introduction into the environment. Shipments of LMOs destined for "contained use" (e.g., in a laboratory) or for intentional introduction into the environment (e.g., microorganisms for bio-remediation, seeds for planting or live fish for

\footnotetext{
25 - Id. art. 15 , at 828

${ }^{26}$ - Id. art 16 , at 829

27 - Id. art. 19 , at 830 .

28 - BIOTECHNOLOGY:SCIENCE, ENGINEERING, AND ETHICAL CHALLENGES FOR THE TWENTY-FIRST CENTURY (Frederick

B. Rudolph \& Larry V. McIntire, eds. 1996).

29 - Parliament/Council Regulation 258/97, 1997 O.J. (L 43) 1

30 - H.R. 3377, 106th Cong. (1999); S. 2080, 106th Cong. (2000).

31 - Cartagena Protocol on Biosafety to the Convention on Biological Diversity, adopted Jan.29, 2000, Montreal $<$ http://www.biodiv.org/biosafe/protocol/html >

32 - Cartagena Protocol, art. 1.
} 
release into lakes) must be accompanied by documentation clearly identifying them as such. ${ }^{33}$

Second, for exports of LMOs that are intended to be introduced into the environment of the importing state, the exporter must also provide detailed information to the importing state in advance of the first shipment, after which the importing state must acknowledge receipt and then provide or deny uthorization for the shipment. ${ }^{34}$ If the permit was issued, Next similar no need to new permition At least until the change in government consent is not created.

Protocol requires government allowed before issuing the permission should assess risks In order to detect the possible harmful effects of this modified organisms for conservation and sustainable use of biodiversity and also to assess the risks to human health. ${ }^{35}$

the importing state is obliged (or is obliged to require the exporter) to conduct a risk assessment based on certain general principles and methodological steps set forth in the Protocol before authorizing or denying the import and, if authorized, thereafter engage in risk management. ${ }^{36}$ Biosafety Protocol created an online database for the purpose of assisting in the exchange of knowledge, technology and environmental and legal information on living modified organisms. ${ }^{37}$

This protocol has limitations such as only living modified organisms to be included also just to note the effects on biodiversity conservation. ${ }^{38}$ Efforts are underway to regulate the status of other genetically modified products like inanimate foods such as cakes made from modified crops and other products such as jeans made from modified cotton or fabrics. All pharmaceuticals are excluded from coverage, while other applications in the medical field also fall outside the scope of the Protocol. Further, the advanced informed agreement procedure does not apply with respect to states that are being transited. ${ }^{39}$ So while the Biosafety Protocol is a major step in creating transparency for risks related to biotechnology exports, particularly for release in the environment and to consider the issue of cross-border Biotechnology But significant gaps in the areas covered by it.

There are a variety of governmental and nongovernmental actors that have disagreement about the level of transparency required for the export of genetically modified A significant doubt about the labeling projects is their relationship with binding treaties about free trade. For example, the protocol requires that a government could ban the import of modified organisms that are going to be released in the environment. ${ }^{40}$

On the other hand provides that the right of every state to regulate and control the entry modified organisms is subject to existing international obligations, including obligations arising from the agreements of the WTO.The protocol also requires that the provisions of this Protocol and the WTO agreements are mutually supportive And should not be interpreted as implicitly requires a change in the rights and obligations of a member under any existing agreements

While at the same time such statements are "not intended to subordinate this Protocol to other international agreements so protocols obscures the relationship between standards and criteria laid down in the Protocol on Biosafety to the standards that apply under trade agreements (and may vary).

\section{The Third Challenge: Imports}

Perhaps the most well-known contemporary concerns about cross-border biotechnology is that the government can ban or limit importing of genetically modified crops because of human health, environmental protection or consumer preferences.Biotechnology exporting governments claim that such prohibitions and restrictions, is inconsistent with the obligations of the General Agreement on Tariffs and Trade ${ }^{41}$ and related agreements such as the Agreement on sanitary measures ${ }^{42}$ and agreements on trade barriers. ${ }^{43}$

The prospect of numerous commercial disputes in this area is readily apparent from the ongoing standoff

33 - - Id., art. 18(2).

${ }^{34}$ - Id., arts. 7-10.

35 - Id., arts. 10(1) \& 15(1).

36 - Id., arts. 15-16 \& annex III.

37 - Id. art. 20

38 - Id., art. $3(\mathrm{~g}) \&(\mathrm{~h})$.

39 - Id., art. 6.

40 - Id., art. 10(3)(b).

41 - General Agreement on Tariffs and Trade, opened for signature Oct. 30, 1947, 61 Stat.A3, 55 U.N.T.S. 194

42 - Agreement on the Application of Sanitary and Phytosanitary Measures, Apr. 15, 1994,

43 - Agreement on Technical Barriers to Trade, Apr. 15, 1994, 
between America and Europe in the field of genetically engineered products. Europeans had serious concerns in the 1990s about the harmful effects to health caused by imported food, especially the spread of mad cow disease. ${ }^{44}$ That concerns were the same in the case of genetically modified crops. ${ }^{45}$ Although until 1998, the European Union approved the imports of some genetically modified crops under its Directive 90/220 ${ }^{46}$ beginning in March 1998 the European Union suspended any further approvals. Then, on June 25, 1999, the EU Council of Environment Ministers in essence ruled out the approval of any new genetically modified organism applications until a revised version of Directive 90/220 was approved by the European Parliament and implemented by the member states. ${ }^{47}$ After this, America corn exports to Europe dropped more than $90 \% .{ }^{48}$ The Europe Union labeling scheme is seen by some as a non-tariff barrier that is designed to support the Europe Union against at lower prices and modified products of US. ${ }^{49}$

In any case, it seems that reconciling these differences under existing international trade agreements is difficult and seems likely to lead to a challenge in the not too distant future and in the absence of a better structure to deal with it. ${ }^{50}$

\section{Liability for Damages}

As was mentioned, it is likely that genetically modified crops be harmful to human health or the environment. When such damage occurs, a person should be responsible for it and in this case must be determined who is responsible for the damage? This becomes more complex when modified products are traded globally Although the science of biotechnology is a symbol of human creative intelligence But many issues are still unknown.Among the unknowns, the spread of gene is introduced This means that how works a specific modified gene when exposed to environmental different factors .There is indeterminable risk of harmful effects for ecosystems, such as damage to non-target species Which can spread to other species in nature. While the threat to ecosystems can be managed by careful assessment of the ecosystem that these genes have been realesed. But the ability to manage these risks is reduced when the genes of living organisms be exported globally. ${ }^{51}$

In addition, there is the risk of gene flow by manipulating the genes of an organism (like a plant) is transmitted unintentionally (eg through pollen) to other plants.National competent authorities are faced with the question of how manage liability resulting from damages caused by genetically modified crops ${ }^{52}$.

Over many years is that the parties of Convention on Biological Diversity intend to pursue a process to elaborate international rules and procedures on liability and compensation for damage resulting from transboundary movement of living modified organisms.

In environmental safety protocols, this process is limited to harmful effects caused by genetically modified organisms. The prospects for success of regulation of the rules and procedures, through this process for the conclusion of international instruments on liability in this field, will be negligible If not supported by the importer governments and exporters of biotech crops (governments and companies). ${ }^{53}$ Many agreements contain provisions to extend liability regimes are but a very small number of them have grown up. ${ }^{54}$ Regimes that have had some success, for example in the field of nuclear energy, it would have been a limited number of

44 - Donald G. McNeil Jr., Europe Plans Advisory Unit on Food Safety, N.Y. TIMES, Jan. 13, 2000, at A16.

45 - Rick Weiss, In Europe, Cuisine du Gene Gets a Vehement Thumbs Down, WASH. POST, Apr. 24, 1999, at A1

46 - Council Directive 90/220 on the Deliberate Release into the Environment of Genetically Modified Organisms, 1990 O.J. (L 117) 15;

47 - EU Environment Ministers Strengthen De Facto Ban on GMOs; WTO Fight Looms, 22 Int'l Env't Rep. (BNA) 567 (July 7, 1999).

48 - Nicole Ballenger et al., Biotechnology Implications for U.S. Corn and Soybean Trade, AGRIC. OUTLOOK, Apr. 2000, at 24, 24-25, $<$ usda.mannlib.cornell.edu /reports /erssor/economics/ao-bb/2000/ao270.pdf>.

49 - John Stephen Fredland, Note, Unlabel Their Frankenstein Foods!: Evaluating a U.S. Challenge to the European Commission's Labeling Requirements for Food Products Containing Genetically-Modified Organisms, 33 VAND. J. TRANSNAT'L L. 183 (2000).

50 - OECD, Report of the Working Group on Harmonisation of Regulatory Oversight in Biotech nology, OECD Doc. C(2000)86/ADD2 at 6 (May 25, 2000).

51 - James M. Tiedje et al., The Planned Introduction of Genetically Engineered Organisms: Ecological Considerations and Recommendations, 70 ECOLOGY 298, 311 (1989)

52 - Richard A. Repp, Comment, Biotech Pollution: Assessing Liability forGenetically Modified Crop Production and Genetic Drift, 36 IDAHO L. REV. 585 (2000)

53 - "Attack of the Killer Tomatoes?" Corporate Liability for the International Propagation of Genetically Altered Agricultural Products, 10 TRANSNAT'L LAW. 153 (1997).

54 - Institut de Droit International,Resolution on Responsibility and Liability Under International Law forEnvironmental Damages,Sept. 4, 1997 , 


\section{Member States. ${ }^{55}$}

There are multiple difficulties unrelated to biotechnology in developing such a legal regime, covering both procedural issues (such as which courts have jurisdiction over the claims and the parties, which parties have standing to bring the claims, and whether judgments are enforceable in another nation's courts) and substantive issues (such as the burden of proof and limitations on liability). But there are additional difficulties linked with some of the concerns discussed in prior sub-sections. If a developing state is entitled to joint benefits when a biotechnology company develops a product using the genetic resources located in the state, arguably liability should be joint if the product causes damage.To the extent equitable concerns argue in favor of distributing biotechnology applications on a lowcost/no-cost basis, arguably a biotechnology company should not be liable or should be minimally liable for ensuing damage. If fully liable, presumably the biotechnology companies will be inhibited from engaging in altruistic behavior.

One must ask whether resolving these complex issues this best is done through a global treaty/protocol, through national legislation, or through private contracting. Perhaps the only means to direct and manage these issues is providing new ways to gain a high level of common understanding and consensus among the relevant actors in the field of cross-border biotechnology.

When crops are genetically modified they may have negative effects on human health or the environment neighboring government Even if they are fully producted and consumed in a state.There are concerns about the emergence of super weeds or insects super at the national and transnational level Because insects and weeds do not respect national borders! To the extent that genetically modified plants and animals are released into the environment, the fact is inevitable that they may entering to territory of neighboring countries.

For instance, salmon have been genetically engineered in the laboratory to be about twice as large as regular salmon; once approved for widespread breeding in the United States or Canada, some scientists fear that engineered salmon will escape from their net pens causing adverse effects on wild salmon, thereby affecting all salmon-harvesting states. ${ }^{56}$

There are general principles of international law, including international environmental law to recognize the national rights of states to exploit their natural resources But at the same time invites governments to not allow the use of land for activities causing damage to the environment of other countries, (such as Article 21 of the Stockholm Declaration) ${ }^{57}$ While these principles are useful in the regulation of specific topics in the field of international relations, But not enough As long as they individually want to address the complex issues of state responsibility for transboundary damage caused by its biotechnological applications.

The International Law Commission has for years been trying to elucidate in greater detail the rules to apply when states cause transboundary damage, either in situations where a wrongful act has occurred or where no wrongful act has occurred. So far, those efforts have not borne fruit. ${ }^{58}$ Moreover, rather than building liability regimes for compensation ex post facto, many believe that greater emphasis should be placed on regulating the emission of pollutants ab Initio before they cause damage to adjacent states, as done in most international environmental agreements.

\section{Conclusion}

With increasing national awareness of the diverse applications of biotechnology saw that these countries are increasingly attracted to use their biotechnology. So that after reviewing the government's international function can be clearly seen from fact that they have done huge investments in this area, both domestically and internationally but after some time and after getting countries to biotechnology applications, gradually appeared disadvantages Biotechnology For example Genetically modified products to poison the insects, May inevitably lead to the poisoning of insects are harmless or beneficial insects When feed from pests and so in fact increase the number of pests and reduces the biodiversity of insects Biotechnology as well as problems at the international level and treaties related to each of them mainly can be placed in several groups:

Concerns about patents of genetically modified crops :National rules of developed countries, have supported

\footnotetext{
55 - Convention on Third Party Liability in the Field of Nuclear Energy, July 29,1960, 956 U.N.T.S. 251, reprinted in 55 AM. J. INT’L L. 1082 (1960)

56 - Carol Kaesuk Yoon, Altered Salmon Leading Way To Dinner Plates, but Rules Lag, N.Y. TIMES, May 1, 2000, at A1

57 - Principle 21 of the 1972 Stockholm Declaration of the United Nations Conference on the Human Environment, U.N. Doc. A/CONF.48/14 (1972), reprinted in 11 I.L.M.1416 (1972).

58 - Ninth Report on International Liability for Injurious Consequences Arising Out of Acts Not Prohibited by International Law, II:1 Y.B. INT'L L. COMM'N 187 (1993)
} 
intellectual property of genetically modified crops. If the grant intellectual property rights to biotech crops, the main part of the world food falls hands of a few capitalist companies.

Environmental Convention on Biological Diversity was adopted in 1992 to address these concerns. The objective of this Convention to consider concerns to ensure free access to genetic resources and promotion of equitable distribution of the benefits of this resources and modified crops. Of course, criticism is expressed about the Convention, including its purpose is the protection of biodiversity have vague and general provisions. For example, it requires that countries should take the appropriate executive and legislative measures to ensure the participation of other countries, especially developing countries in biotechnological projects to But it does not set examples.America also accepted the Convention Because The Convention requires too much government intervention over transactions of concerned private parties And also did not recognize property rights.

Transparency about the risks related to export genetically modified crops:Notice that products importing the country are genetically modified product, is possible through system of labeling.Biosafety Protocol was adopted in 2000 to address concerns in relation to the promotion of transparency.This protocol created an international framework for addressing environmental risks and effects of some genetically modified crops .As well as under this Protocol, trade of these products are contingent to some factors. For exports of LMOs that are intended to be realesed into the environment of the importing state, the exporter must provide detailed information to the importing state in advance of the first shipment, after which the importing state must acknowledge receipt and then importing state should also have a risk assessment and then give permission to enter the product.

Biosafety Protocol created an online database for the purpose of assisting in the exchange of knowledge, technology and environmental and legal information on living modified organisms. Of course this protocol is associated with limitations

Including the fact that only covers the living modified organisms (not, for example, artificial fibers) Or just pay attention to the effects on biodiversity conservation (not, for example, the effects on human health) Or in advanced notification procedures runs only when these products are going to release in nature of importing country (And not there when they want to be used as food).

Liability for damage caused by genetically modified imported goods: We know that there is a non-determination risk of harmful effects of these products for ecosystems Including damage to non-target species and spread to other species In these cases, a major question arises that When such damage occurs, a personshould be responsible for it And in this case must be determined who is responsible for the damage?

To answer this question, Convention on Biological Diversity and the Biosafety Protocol have made efforts. In this way that attempted to create international rules on liability and compensation for damage caused by genetically modified crops. Of course, in Biosafety Protocol, these provisions were limited to the harmful effect caused by genetically modified organisms. In this regard, there is some doubt whether the partnership of developing countries in interests of these products leads to sharing liability arising from damage? Or exclusive responsibility of companies exporting these products may lead to avoidance of them for humanitarian actions in poor countries or allowing these products by the importer with knowledge of the risk and damage would assume responsibility for damages caused by it.

Liability relating to transboundary damage caused by genetically modified crops: When crops are genetically modified they may have negative effects on human health or the environment neighboring government Even if they are fully producted and consumed in a state.Article 21 of the Stockholm Declaration provides governments to not allow the use of land for activities causing damage to the environment of other countries.Of course, this legal principle is not enough to solve the complex problems arising from state responsibility of cross-border losses caused by biotechnological applications What can be stated as a conclusion that There is no specific and unit regime to address biotechnological concerns But we have a network of treaties relating to intellectual property, trade and the environment Which in some cases conflict with each other. And also we are faced with a series of general and vague legal principles and norms Due to the important concerns related to biotechnology and its impact in order to address these problems in international law there must be steps taken in this regard.Also there is a need for coordination between the various treaties regimes (intellectual property, trade and environment) in the field through the formation of working groups composed of scientists, environment lovers, international traders, business organizations and academic groups.

\section{References}

Allison A. Snow \& Pedro Morán Palma, Commercialization of Transgenic Plants: Potential Ecological Risks, 47 BIOSCIENCE 86, 93 (1997). 
Andrew Pollack. (2000). New Ventures Aim to Put Farms In Vanguard of DrugProduction, N.Y. TIMES, May 14, 2000 , at 1 .

Budapest Treaty on the International Recognition of the Deposit of Microorgans for the Purposes of Patent Procedure, Apr. 28, 1977, 32 U.S.T. 1241, 17 I.L.M. 285.

Calgene, Inc., Availability of Letter Concluding Consultation, 59 Fed.Reg. 26,647 (Dep’t Health \& Human Services 1994).

Carol Kaesuk Yoon, Altered Salmon Leading Way To Dinner Plates, but Rules Lag, N.Y. TIMES, May 1, 2000, at A1.

Carol Kaesuk Yoon, No Consensus on the Effects Of Altered Corn OnButterflies, N.Y. TIMES, Nov. 4, 1999, at A15.

Carol Kaesuk Yoon, Squash With Altered Genes Raises Fears of "Superweeds," N.Y. TIMES, Nov. 3, 1999, at A1.

David A. O'Brochta \& Peter W. Atkinson, Building the Better Bug, SCI. AM., Dec. 1998, at 90.

Donald G. McNeil Jr., Europe Plans Advisory Unit on Food Safety, N.Y. TIMES, Jan. 13, 2000, at A16.

Hvoslef-Eide \& Odd Arne Rognli, Environmental Issues for Plant Biotechnology Transfer: A Norwegian Perspective, in PLANT BIOTECHNOLOGY TRANSFER TO DEVELOPING COUNTRIES 37, 38-39.

James Kling, Could Transgenic Supercrops One Day Breed Superweeds? 274 SCI. 180 (1996).

Janet Raloff, an Alaskan Feast for Oil-Eating Microbes, 143 SCI. NEWS 253 (1993). http://dx.doi.org/10.2307/3977130

Marc Kaufman, Biotech Critics Cite Unapproved Corn in Taco Shells, WASH. POST, Sept. 18, 2000, at A2;

Michael J. Malinowski, Globalization of Biotechnology and the Public Health Challenges Accompanying It, 60 ALB. L. REV. 119 (1996).

Michael Pollan, Playing God in the Garden, N.Y. TIMES, Oct. 25, 1998,6Magazine at 44.

Plant Pesticides: Recent Developments in the EPA's Regulation of Biotechnology, 7 U. FLA. J.L. \&PUB. POL'Y 257 (1996).

Richard A. Repp, Comment, Biotech Pollution: Assessing Liability forGenetically Modified Crop Production and Genetic Drift, 36 IDAHO L. REV. 585 (2000).

Rick Weiss \& Justin Gillis. (2000). DNA-Mapping Heralded, WASH. POST, June 27.

Rick Weiss, Corn Seed Producers Move to Avert Pesticide Resistance, WASH. POST, Jan. 9, 1999, at A4.

Rick Weiss, In Europe, Cuisine du Gene Gets a Vehement Thumbs Down, WASH. POST, Apr. 24, 1999, at A1.

Robert B. Horsch, Biotechnology and Sustainable Development, in BIOTECHNOLOGY AND BIOSAFETY 25 (Ismail Serageldin \& Wanda Collins eds., 1999).

Robert F. Service, Seed- Sterilizing ‘Terminator Technology' Sows Discord, 282 SCI. 850 (1998).

Rochelle Cooper Dreyfuss \& Dorothy Nelkin, the Jurisprudence of Genetics, 45 VAND. L. REV. 313 (1992).

Sheryl Gay Stolberg, the Biotech Death of Jesse Gelsinger, N.Y. TIMES, Nov.28, 1999.

Ya-Ping Tang et al. (1999). Genetic Enhancement of Learning and Memory in Mice, 401 NATURE 63.

\section{Copyrights}

Copyright for this article is retained by the author(s), with first publication rights granted to the journal.

This is an open-access article distributed under the terms and conditions of the Creative Commons Attribution license (http://creativecommons.org/licenses/by/4.0/). 